on the whole brought forward evidence contrary to that of Virtanen.

It may be generally assumed that the excretion and donation obtained by Virtanen are associated with some environmental factors not readily reproducible elsewhere.

In more recent experiments carried out at the Waite Institute, attempts have been made to grow peas and oats in association under a variety of conditions, which included variations in the amount of daylight and in the moisture content of the soil. It might be assumed that a reduction in the amount of photosynthesis in a well-established leguminous plant might result in an accumulation of nitrogen compounds above the needs of the plant, such excess being excreted and made available for any associated non-legume.

In these experiments in a series of pots, a mixture of oats and inoculated peas and oats alone were grown in pure sand under favourable conditions for a period of six weeks-the peas at the end of this period were vigorous and healthy. A differential treatment was then imposed for a further six weeks on half of the pots. These pots were allowed two hours of daylight only each day, between the hours of noon and 2 p.m. The atmospheric conditions favoured high transpiration.

Each pot contained either two oat plants alone or two oat plants and two pea plants.

TOtal NITROGEN (MGM.) IN OAT PLANTS PER POT.

\begin{tabular}{|c|c|c|c|c|c|}
\hline \multirow[b]{2}{*}{ Replicate } & \multicolumn{2}{|c|}{$\begin{array}{l}\text { Normal daylight, } \\
\text { approx. } 11 \text { hours daily }\end{array}$} & \multicolumn{2}{|c|}{$\begin{array}{l}\text { Reduced daylight } \\
2 \text { hours daily }\end{array}$} & \multirow[b]{2}{*}{ Mean } \\
\hline & Oats alone & Oats with & Oats alone & Oats with & \\
\hline 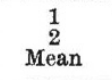 & $\begin{array}{l}4 \cdot 09 \\
3 \cdot 91 \\
4 \cdot 00\end{array}$ & $\begin{array}{l}3 \cdot 83 \\
3 \cdot 14 \\
3 \cdot 48\end{array}$ & $\begin{array}{l}5 \cdot 01 \\
5 \cdot 66 \\
5 \cdot 34\end{array}$ & $\begin{array}{l}7 \cdot 10 \\
6 \cdot 84 \\
6 \cdot 97\end{array}$ & $\begin{array}{l}5 \cdot 01 \\
4 \cdot 89 \\
4 \cdot 95\end{array}$ \\
\hline
\end{tabular}

The standard error of a single observation is $\pm 0 \cdot 35$.

The increases in the total nitrogen content of the oats brought about by shading or by association with peas are independently significant, statistically. The legume effect is significant when the effect of shading upon the oats alone is eliminared.

In no circumstances have we ever been able to obtain evidence of donation in controlled pot experiments under the normal growing conditions in Adelaide. It is of interest that we have been able to obtain evidence of apparent donation by some modification of the local environment.

T. H. STRONG.

H. C. TRumble.

Waite Agricultural Research Institute, Adelaide.

Dec. 24.

${ }^{1}$ Virtanen, A. I., and Laine, T., J. Agric. Sci., 27, 332 (1937), etc. Wilson, P. W., NATURE, 140, 155 (1937).

${ }^{3}$ Bond, G., Ann. Bot., n.s., 2, 61 (1938).

-Trumble, H. C., and Strong, T. H., C.S.I.R. (Aust.) Bull., 105, 11-24 (1937).

\section{Respiration Changes following Irradiation with $\mathrm{X}$-rays}

IN a study of respiratory changes prior to tumour formation after irradiation with X-rays, two disturbances in the oxidation processes of the affected tissues were observed. A group of sixteen mice were given local treatment of X-rays sufficient to produce a burn. At various intervals after irradiation ( 3 hours-50 days), mice were successively sacrificed and the respiration of the irradiated area compared to the respiration of an equal control area on the same mouse. It was observed that, after the first day of irradiation, the respiration began to decrease, reaching a maximum depression, after about two weeks, of 60 per cent below the respiration of the control skin. Directly following this period of inhibition was a period of stimulation which brought the oxygen consumption of the irradiated area of skin about 35 per cent above that of the control. This stimulation continued over a period of about five weeks.

It has not been determined at this time whether the initial decrease in oxygen consumption is due to a degeneration and dying of the irradiated cells, and the subsequent stimulation of respiration due to an invasion of leucocytes and new tissue cells, or whether irradiation has more directly altered the respiratory mechanism of the cells.

These results are of particular interest in view of the experiments of Davis ${ }^{1}$, which show that the resistance or susceptibility of animals to cancer is dependent upon the respiration of the normal tissues of these animals. There also remains the possibility that a relationship exists between tissue respiration and lymphocytic invasion; for it has been demonstrated by Murphy et al. ${ }^{2}$, that when lymphocytosis is prevented by proper dosages of X-rays, the resistant state is abolished. Erythema doses (Murphy ${ }^{3}$ ), however, considerably reduce the percentage of 'takes' of autografts.

The fact that $\mathrm{X}$-rays can both stimulate and depress tissue respiration may explain why X-rays can both decrease and increase the resistance of animals to transplantable tumours.

\section{John C. Fardon.}

William A. Sullivan.

Institutum Divi Thomae, Cincinnati, Ohio.

Dec. 17.

'Davis, J. E., Canadian Med. Assoc. J., 36, 27-30 (1937). ${ }^{2}$ Murphy, James B., and Morton, John J., J. Exp. Med., 22, 204

${ }^{3}$ Murphy, James B., Maisin, Joseph, and Sturm, Ernest, J. Exp. Med., 33, 645 (1623).

\section{Induction of Polyploidy by Pulp and Disintegrating Tissues from Colchicum sp.}

Investigations of the active agents in Nature inducing chromosome alterations have shown that the most effective ones are abnormal temperatures ${ }^{1}$ and obviously various parasites (cynipid wasps ${ }^{2}$, nematodes $^{3}$, Eryophyes ${ }^{4}$, Tetranychus ${ }^{5}$, bacteria ${ }^{6}$, fungi ${ }^{7}$, viruses ${ }^{8}$, etc.). The latter induce abnormalities in the mitotic and meiotic processes chiefly by introducing various substances and partly by woundings, which further give rise to plants with altered chromosome complexes (including polyploidy ${ }^{6}$ ).

This type of work in connexion with the induction of chromosome alterations (chiefly polyploidy) by the alkaloid colchicine ${ }^{2}$ obtained from Colchicum autumnale suggested the following experiments: (1) Does pulp from Colchicum bulbs induce chromosome alterations? (2) Do disintegrating pieces from the bulbs induce chromosome alterations and particularly polyploidy in seedlings from germinating seeds in the neighbourhood? Experiments performed showed that about two grams of pulp from Colchicum sp. bulb induced swellings (like low concentrations from colchicine-induced) in seedlings when seeds from Triticum, Secale and Crepis were germinating on the 